\title{
ADDITÍV FÉMNYOMTATÓ SZERSZÁMGÉPEK
}

\author{
Kiss Lotár László \\ gépészmérnöki szakos MSc hallgató, Miskolci Egyetem \\ 3515 Miskolc, Miskolc-Egyetemváros, e-mail: lotar@skylan.hu
}

\begin{abstract}
Absztrakt
A 3D-nyomtatás, mint újszerü gyártási módszer egyre inkább terjed, és borírtja fel a megszokott ipari konvenciókat. Míg eddig leginkább müanyag alkatrészek gyártásában kapott föszerepet, jelenleg egyre jobban terjednek a fém alapanyagú verziók is. Neves szerszámgép gyártók, mint pl. a DMG Mori, vagy a GE szállnak versenybe egymással, hogy a technológiát megvalósitó berendezéseket alkossanak az ipar számára, ahol pedig egyre növekvö piaca van az ilyen gépeknek. Cikkem igyekszik választ adni arra a kérdésre, hogy hol van a helye ezeknek az eszközöknek az iparban, tekinthetöek-e szerszámgépeknek és alkalmazhatóak-e rájuk a szerszámgépek felépitését leíró/feltáró eljárások.
\end{abstract}

Kulcsszavak: fémnyomtatás, 3D nyomtatás, szerszámgép, definíció, morfológia, funkcióblokk-vázlat

\begin{abstract}
The 3D printing, as a modern manufacturing method, is becoming more widespread and overrides the usual industry conventions. While it was mainly known in the production of plastic parts, nowadays metal-based versions are also becoming more widespread. Reputable machine tool manufacturers such as DMG Mori or GE compete with each other to create equipment for this technology for the industry, where there is a growing market for such machines. My article seeks to answer the question of where these tools have a place in the industry, whether they can be considered as machine tools, and decide that the procedures describing the construction of machine tools could be applied to them.
\end{abstract}

Keywords: metal printing, 3D printing, machine tool, definition, morphology, function block sketch

\section{Bevezetés}

A fémnyomtató eljárások, hasonlóan a müanyagos változatokhoz, az RPT (rapid prototyping, gyors prototípusgyártó) eljárásokból származtathatóak, és ezek az alapok a jelenleg iparban használt gépeken is felfedezhetőek. Habár az elnevezések sok esetben eltérnek, de alapvetően a legtöbb megvalósítás a DED (direct energy deposition, lézeres felrakóhegesztés), és a PBF eljárás (powder bed fusion, porágyas öszszeolvasztás) valamelyik alváltozataként kezelhetö.

Míg a lézeres felrakóhegesztés esetében a munkadarabot lehet bővíteni további geometriákkal, akár egy CNC forgácsoló szerszámgépbe szerelt plusz fej segítségével (hibrid megmunkálás), addig a PBF esetében fémporból, rétegenként, egy lézer energiájának segítségével épül fel a teljes munkadarab. Mivel ez utóbbi tekinthető önálló eljárásnak és berendezésnek, ezért a továbbiakban a cikk erre a technológiára, és ezt a technológiát megvalósító megmunkáló berendezések vizsgálatára korlátozódnak. Cikkünkben röviden kitérünk a fémnyomtató berendezések felhasználási területeinek ismertetésére, vázoljuk szerszámgépek területén jelenleg elfogadott pozícióját, struktúraelrendezéseit, funkciókból fakadó strukturális megkötéseket, részegységek összevető vizsgálatát, valamint valós struktúraváltozatokat is bemutatunk. 


\section{Az ipari fémnyomtatás gyakorlati alkalmazásai}

A fémnyomtató eljárásokat kutatva felmerülhet a kérdés, hogy miért van az egész technológiára szükség egyáltalán. Számtalan olyan munkadarab létezik, amelyet hagyományos technológiákkal nem, vagy csak nagyon nehezen lehet megvalósítani - ilyen pl. az alkatrész belsejében futó hütőcsatornák esete, a nagy elforgácsolandó anyaghányaddal rendelkező alkatrészek esete, vagy a nehezen megmunkálható anyagminőségek és bonyolult geometriák kombinációja.
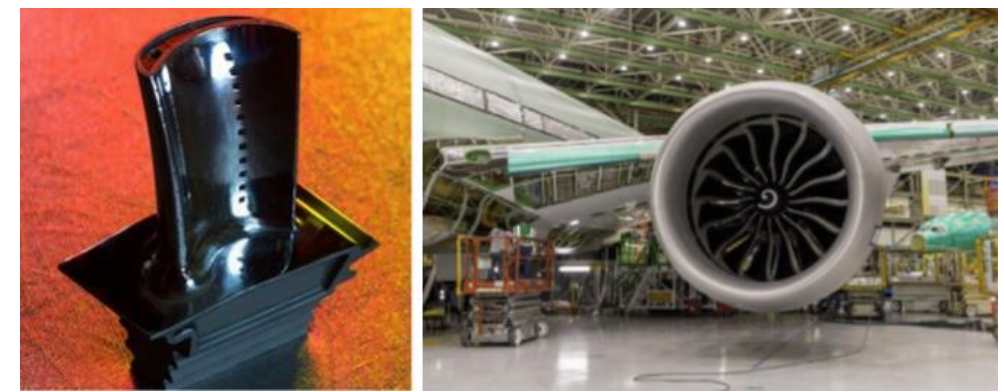

1. ábra. A Boeing hajtómüvek 3D nyomtatott Ti-Al ötvözet lapátjai (Blades, Bones, 2013)

Egy konkrét példát mutat az 1. ábra, ahol a Boeing Ti-Al ötvözetü magas hőmérsékleten igénybevett turbinalapátokat alakít ki belső hütőcsatornákkal. Egy ilyen geometria, ilyen anyagból történő kialakítása hagyományos eljárásokkal nem gazdaságos, és rendkívül körülményes.

A 2. ábra egy másik példát mutat, amely megmutatja, hogy a fémnyomtatás új lehetőségeket ad a tervezés területén is. A két alkatrész terhelhetőség szempontjából azonos merevséget nyújt, mégis látható, hogy az alsó változat töredéke annyi anyagból elkészíthető, mint a forgácsolt verzió.

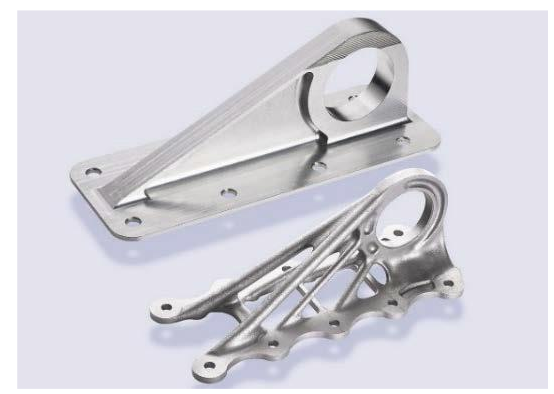

2. ábra. Egy konzol lehetséges kialakitása forgácsolással, és 3D nyomtatással (GE, 2017)

A két alkatrész geometria teljesen más tervezési megközelítést igényel, míg az elsőnél minél egyszerübb alakzatokat, a szerszámokkal való hozzáférhetőséget kell szem előtt tartani, a másik esetben a funkcionális felületet közötti leghatékonyabb térkitöltést és összeköttetést. Ez lehetőséget biztosít pl. az autóiparban jelenleg trendnek számító tömegcsökkentés kivitelezésére, amit ilyen mértékben hagyományos eljárásokkal nem lehetett eddig megoldani.

\section{A fémnyomtató berendezés, mint szerszámgép}

Egy fontos, és jelenleg az iparban is vitatott kérdés, hogy tekinthetőek-e ezek a gépek szerszámgépnek. E kérdés eldöntéséhez a szerszámgép (Takács et al., 2009 b)-ban említett definícióját veszem segítségül. 
„A szerszámgép tágabb értelemben olyan gép, amely a munkadarabokat a gépbe fogott szerszámokkal az ember által közölt információ szerint, emberi erőkifejtés nélkül alakitja át.

A munkadarab anyaga szerint fém-, fa-, müanyag-stb. megmunkáló szerszámgépeket különböztetnek meg."

A definíció tágabb értelmü megfogalmazása mindenféle módosítás nélkül értelmezhető PBF berendezésekre is, ha a munkadarabnak a port, a szerszámoknak pedig a lézert vesszük. Értelemszerüen ezek a gépek a fémmegmunkáló szerszámgépek csoportjába tartoznak.

„,Szükebb értelemben a szerszámgépek fémmegmunkáló gépek, melyek lehetnek forgács nélküli megmunkáló szerszámgépek (sajtók, kalapácsok, hengerlö, hajlitó, stb.), és forgácsoló szerszámgépek (esztergák, fúró-, maró-, gyalu-, vésö-, köszörügépek, fogaskerék-megmunkáló gépek, stb.).

...

Az iparban a legfontosabb gépek a szerszámgépek mert a gépek közül csak a szerszámgépek képesek saját maguk reprodukálására, de bármilyen más gépet is el lehet velük késziteni."

A szükebb definícióban ugyan konkrétan nincs ezeknek a gépeknek kategória még, vagy a forgács nélküli gépek közé lehet őket sorolni, vagy megfontolandó hogy későbbiekben a ,forgácsoló” szó helyett „,anyag elvételével/hozzáadásával” jelenjen meg.

Minthogy a definíció kulcsmondata az, hogy az ilyen gép legyen képes önmaga reprodukciójára, ami maximálisan teljesül ezekre a gépekre, a cikk további részében szerszámgépeknek tekintem a PBF fémnyomtató berendezéseket.

\section{Konstrukciós megkötések, és sajátosságok}

A vizsgálat megkezdése elött általánosságban érdemes megnézni, hogy milyen kötöttségekkel és sajátosságokkal rendelkeznek a PBF fémnyomtató szerszámgépek, amihez tekintsük a 3. ábra vázlatát.

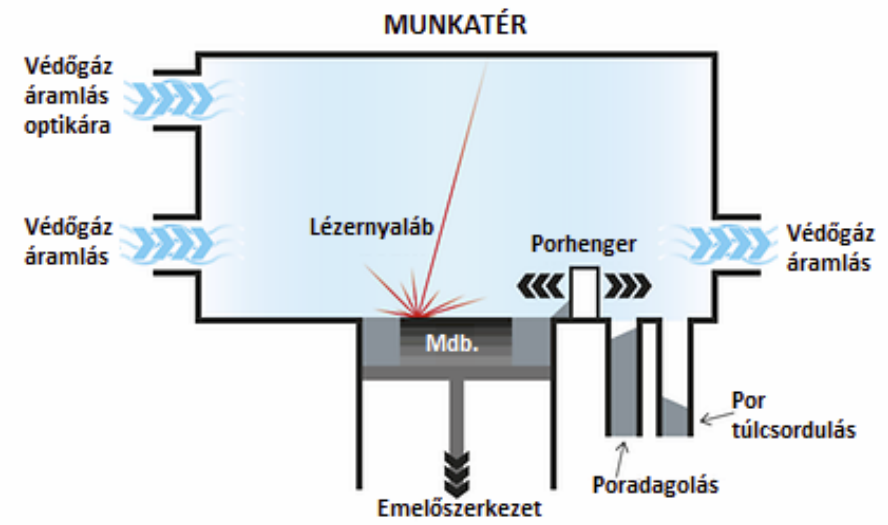

3. ábra. Additív gyártás szelektív lézeres olvasztással (SLM) porágy esetén (DMG Mori)

Mind az ábra, mind pedig az elterjedt ipari megvalósítások azt mutatják, hogy a PBF gépek müködése úgy modellezhető, hogy van egy porágy és egy porhenger, ahol az ágy süllyesztését követően a porhenger elterít egy rétegvastagságnyi port.

A porréteg elterítése után egy lézernyalábbal végigpásztázzák a munkadarab teljes keresztmetszetét, majd az asztal süllyedését követően a folyamat ismétlődik. Az eljárás müködésének menetét vizsgálva az alábbi kötöttségek állapíthatóak meg: 
1. A por elterítése gravitációs módon a legegyszerübb, ezért az asztalnak alul, vízszintes helyzetben kell elhelyezkednie.

2. A lézernek a porágy ellenoldalán kell elhelyezkednie, így az felülről fog dolgozni.

3. A lézernek le kell tudnia fedni a teljes munkateret úgy, hogy lehetőleg egy adott határszögnél laposabb szögben $\left(\sim 5^{\circ}\right)$ ne essen be, mivel akkor inkább olvaszt oldalra, mint lefele.

4. A védőgáz ellátás lehetőleg lamináris legyen, hogy ne kavarja fel az ágyról a port.

Ez meglepően sok kötöttség egy CNC forgácsoló géphez képest, viszont látható lesz később, hogy a lézer mozgatását tekintve így is nagyon sok lehetőség lesz.

A sajátosságok vizsgálata előtt érdemes a (Takács et al., 2009 a) forrás alapján a D-szám definícióját ismertetni, hogy miként értelmezhető ez ilyen szerszámgépek esetén.

„A soros kinematikájú szerszámgépeknél „D”:

az alakitási mechanizmusban lévö azon részegységek száma, melyek valamilyen elemi transzformációt (eltolást, vagy elforgatást) képesek önállóan és egyidőben megvalósitani, a szerszám és a munkadarab közötti relativ mozgás létrehozása során"

A definíció szerint, mivel csak az önálló, és egyidejű mozgás megvalósításokat kell figyelembe venni megállapítható, hogy a PBF szerszámgépek 2D-sek (vagy az ipari konvenciók szerint 2,5D-nek is nevezhetö), hiszen az asztal mozgatása nem egyidejű a lézer mozgatásával, és mindössze csak pozícionáló, léptető szerepet tölt be. Belátható az is, hogy az asztal mozgását, a lézer fel-le mozgatása nem tudja helyettesíteni, mivel ez a porterítéshez szükséges.

Korábban a szerszámgép definíciójának újraértelmezése során egy analógia lett felállítva, miszerint a lézer a szerszám, és a por a munkadarab. Ennek megfelelően a továbbiakban, a porasztalra merőleges, a lézerböl kifele mutató tengely lesz a szerszámgép $Z+$ tengelye, és a többi tengely pedig ennek megfelelően jobbsodratú koordináta-rendszert kialakítandóan megválasztott.

\section{A lehetséges szerszámgép struktúrák mozgásmegosztás és rendű́ség alapján}

Habár a korlátok nem adnak arra vonatkozóan elöírást, hogy soros, párhuzamos, vagy vegyes kinematikai láncú gépet kell építeni, a továbbiakban a soros megoldások kerülnek vizsgálatra, mivel ezek egyszerübbek, és jobb munkatér lefedéssel rendelkeznek (Takács et al., 2009 a). A kötöttségek és sajátosságok figyelembevételével a mozgásmegosztás és rendűség alapján megvalósítható szerszámgép struktúrákat a 1. táblázat. A lehetséges másodfokú szerszámgép struktúrák1. táblázat tartalmazza.

1. táblázat. A lehetséges másodfokú szerszámgép struktúrák

\begin{tabular}{|r|c|c|}
\hline & Elsőrendü megoldások & Másodfokú megoldások \\
\hline 1. & \multirow{2}{*}{$\mathrm{X}(\mathrm{m}), \mathrm{Y}(\mathrm{m})$} & $\mathrm{X}(\mathrm{m}, 1), \mathrm{Y}(\mathrm{m}, 2)$ \\
\cline { 1 - 1 } 2. & $\mathrm{X}(\mathrm{m}), \mathrm{Y}(\mathrm{s})$ & $\mathrm{X}(\mathrm{m}, 2), \mathrm{Y}(\mathrm{m}, 1)$ \\
\hline 3. & $\mathrm{X}(\mathrm{s}), \mathrm{Y}(\mathrm{m})$ & $\mathrm{X}(\mathrm{m}, 1), \mathrm{Y}(\mathrm{s}, 1)$ \\
\hline 4. & \multirow{2}{*}{$\mathrm{X}(\mathrm{s}), \mathrm{Y}(\mathrm{s})$} & $\mathrm{X}(\mathrm{s}, 1), \mathrm{Y}(\mathrm{m}, 1), \mathrm{Y}(\mathrm{s}, 2)$ \\
\hline 5. & & $\mathrm{X}(\mathrm{s}, 2), \mathrm{Y}(\mathrm{s}, 1)$ \\
\hline & &
\end{tabular}

A lehetséges variációkat áttekintve két lehetőség közül lehet válogatni - a porasztal, illetve a lézer oldalirányú mozgatása. Az első esetben figyelembe kell venni, hogy a porasztal, ha teljesen meg van töltve porral, akár több tonna tömeget is jelenthet, ezért ennek precíz mozgatása így nehézkes, és körülményes. 
A lézernyaláb oldalirányú mozgatásának megoldásaként szóba jöhetnek tükrök, illetve maga a lézer egység mozgatása - első esetben az optikai eszközök védelme válik kihívássá, míg a második esetben pedig a védelem mellett még pl. az erősáramú kábelek megtörésének veszélye is fennáll.

Figyelembe véve, hogy milyen pontossági követelmények vannak ezekre a gépekre elöírva, és hogy a porasztal tömege milyen komoly kihívást jelentene mozgatási szempontból, sokkal egyszerübb a lézersugár mozgatását a megfelelő védelem biztosítása mellett megoldani - így megállapítható, hogy a szerszámra szuperponált PBF szerszámgépek kialakítása a legcélszerübb.

\section{A PBF nyomtató fontosabb részegységeinek összehasonlító vizsgálata}

Hasonlóan a forgácsoló szerszámgépekhez az iparban alkalmazott PBF szerszámgépek is kereskedelmi, vagy egyedileg gyártott részegységekből épülnek fel. Sok esetben ezek a részegységek, feladatukat, elhelyezkedésüket tekintve megfeleltethetőek a forgácsoló szerszámgépekben alkalmazott egységekkel. Az összevetendő részegységeket a

2. táblázat mutatja.

A vizsgálathoz az ún. funkcióblokk-vázlatok kerültek elkészítésre (formátumukat a (Takács et al., 2009 b) forrás tartalmazza), melyek jól áttekinthető grafikus formátumban megmutatják, milyen funkciókat kell megvalósítaniuk a részegységeknek, és összehasonlíthatóságot biztosítanak eltérő megoldások között.

Példaként a 4. ábra bemutatja a lézer és védőgáz- és porkezelő alrendszer funkcióblokk vázlatát. Ha a forgácsoló gépek ábráit vesszük alapul a (Takács et al., 2009 b) forrást felhasználva látható, hogy a lézer-orsómotor kapcsolatnál komoly eltérések, míg a másik esetben komoly hasonlóságok vannak. 


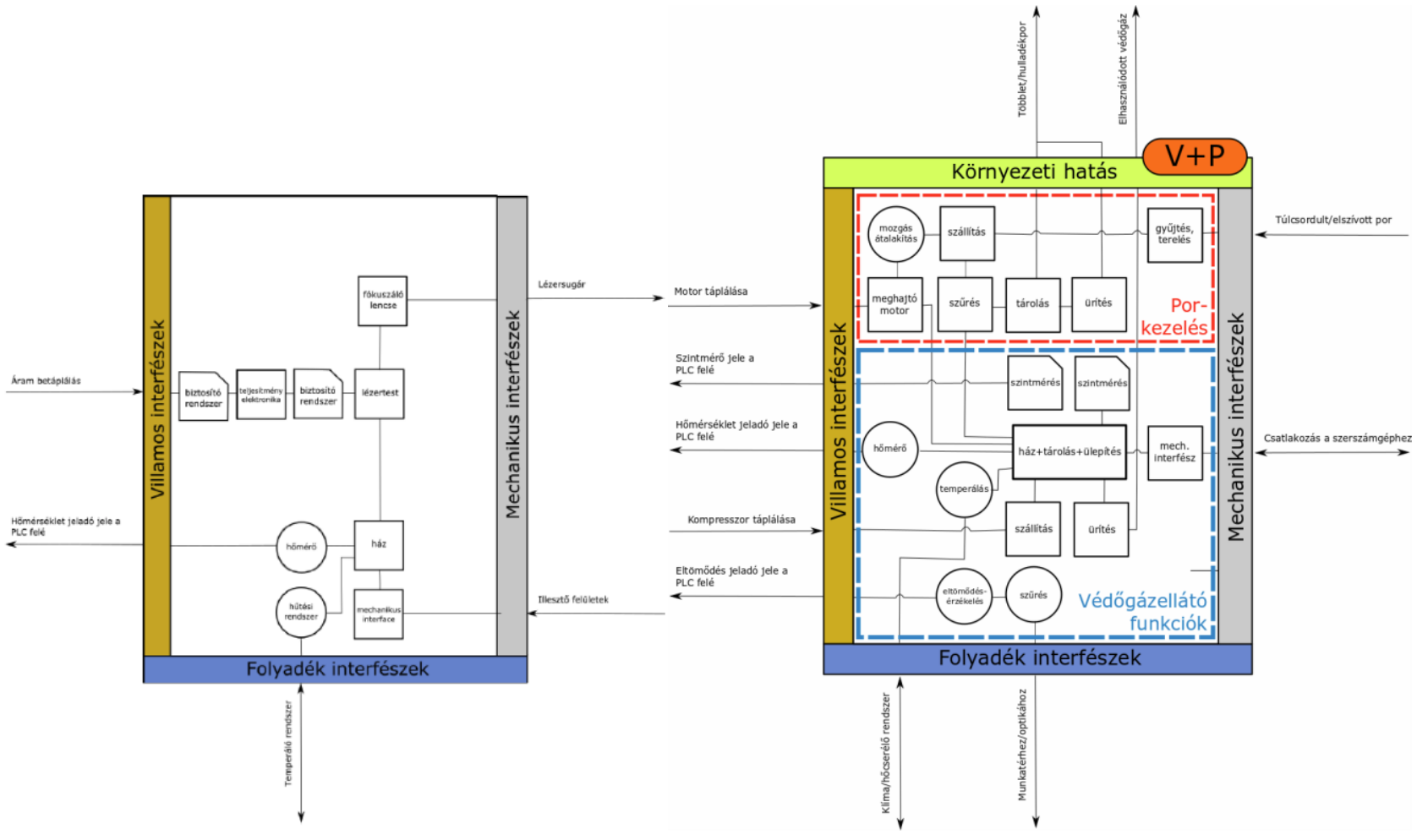

4. ábra. A lézer (bal), és a védőgáz/porkezelés (jobb) funkcióblokk-vázlata (Kiss, 2020)

2. táblázat. Az összehasonlitandó szerszámgép részegységek

\begin{tabular}{|c|c|}
\hline Forgácsoló sz.gép. & PBF szerszámgép \\
\hline Orsómotor & Lézer \\
\hline Hütö-kenő rendszer & Védőgáz ellátó rendszer \\
\hline Forgácskezelő rendszer & Porkezelő rendszer \\
\hline \multicolumn{2}{|c|}{ Burkolatok } \\
\hline \multicolumn{2}{|c|}{ Szánrendszerek } \\
\hline Munkadarab-ellátó rendszer & Poreltávolító rendszer \\
\hline \multicolumn{2}{|c|}{ Tartóelemek, állványok } \\
\hline Szerszám-ellátó rendszer & Porhenger \\
\hline - &
\end{tabular}

\section{Egyes gyártók konkrét megvalósításai}

A piacon kapható jelenlegi ipari megvalósításokat áttekintve megállapítható, hogy a dolgozat korábbi megállapításai alkalmazhatóak ezeknek a vizsgálatakor is. Definiálhatóak olyan fogalmak ezekre a gépekre is, mint munkatér, megmunkálási pontosság, és fellelhetőek a korábban ismertetett részegységek, és sajátosságok is. 
A gépeket egy terjedelmes tudás-mátrixba összefoglalva (Kiss, 2020) megállapíthatóak olyan átlagos paraméterek, amelyek körül mozognak a jelenleg piacon levő szerszámgépek, és később további tervezési feladatokhoz alkalmazhatóak. Ilyen értékek például a 350 × 350 × 350 mm-es munkatér méret, vagy a $\pm 0,03 \mathrm{~mm}$-es pozícionálási pontosság, melyek a legtöbb gépre illeszthetőek.

\section{8. Összefoglalás}

A cikk bemutatta a korszerü additív fémnyomtató eljárásokat, azok lehetőségeit, és iparban való elterjedtségüket. A szerszámgépek definíciójának újraértelmezésével megállapítható, hogy ezek a gépek igenis tekinthetőek szerszámgépeknek, és ezt alátámasztandó, ismertetésre került, hogy miként lehet a szerszámgép morfológiai, és a funkcióblokk-vázlatok segítségével vizsgálni ezeket a korszerủ szerszámgépeket. A jelenleg piacon kapható berendezéseket tudás-mátrixban számba véve megállapíthatóvá váltak átlagos paraméterek, amelyek a funkcióblokk-vázlatokkal együtt alapot szolgáltathatnak PBF fémnyomtató szerszámgépek tervezéséhez.

\section{Irodalom}

[1] Blades and Bones (2013, September). The many faces of 3D printing. www.ge.com

[2] (2017, June). 3D-printed 'bionic' parts could revolutionize aerospace design. www.ge.com

[3] Takács, Gy., Zsiga, Z., Szabóné Makó, I., Hegedűs, Gy. (2009). Gyártóeszközök módszeres tervezése. Nemzeti Tankönyvkiadó. TAMOP 4.2.5

[4] Takács, Gy., Szilágyi, A., Demeter, P., Barak, A. (2009). Forgácsoló szerszám-gépek. Nemzeti Tankönyvkiadó.

[5] DMG Mori LASERTEC 30 SLM hivatalos specifikációi. en.dmgmori.com

[6] Kiss, L. (2020). Additív fémnyomtató szerszámgépek. Tudományos diákköri dolgozat. Miskolc 